Original Article

\title{
Insects and spiders on Acacia mangium (Fabaceae) saplings as bioindicators for the recovery of tropical degraded areas
}

\author{
Insetos e aranhas em plantas de Acacia mangium (Fabaceae) como bioindicadores na \\ recuperação de área tropical degradada
}

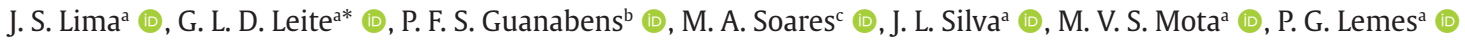 \\ and J. C. Zanuncio ${ }^{\mathrm{d}}$ (D) \\ aUniversidade Federal de Minas Gerais - UFMG, Instituto de Ciências Agrárias, Insetário G.W.G. Moraes, Montes Claros, MG, Brasil \\ 'Instituto Federal de Minas Gerais - IFMG, Campus de São João Evangelista, São João Evangelista, MG, Brasil \\ 'Universidade Federal dos Vales do Jequitinhonha e Mucuri - UFVJM, Departamento de Agronomia, Diamantina, MG, Brasil \\ dUniversidade Federal de Viçosa - UFV, Departamento de Entomologia/BIOAGRO, Viçosa, MG, Brasil
}

\begin{abstract}
Acacia mangium is a pioneer species with fast growth and frequently used in the recovery of degraded areas. The objectives were to evaluate insects and spiders, their ecological indices and interactions on A. mangium saplings in a tropical degraded area in recovering process. The experimental design was completely randomized with 24 replications, with treatments represented by the first and second years after $A$. mangium seedling planted. Numbers of leaves/branch, branches/sapling, and ground cover by A. mangium saplings, Hemiptera: Phenacoccus sp. and Pachycoris torridus; Hymenoptera: Tetragonisca angustula and Trigona spinipes, Brachymyrmex sp., Camponotus sp. and Cephalotes sp.; Blattodea: Nasutitermes sp. and Neuroptera: Chrysoperla sp.; abundance, species richness of pollinating insects, tending ants, and the abundance of Sternorrhyncha predators were greatest in the second year after planting. Numbers of Hemiptera: Aethalium reticulatum, Hymenoptera: Camponotus sp., Cephalotes sp., Polybia sp., T. angustula, T. spinipes, tending ants, pollinating insects, Sternorrhyncha predators and species richness of tending ants were highest on A. mangium saplings with greatest numbers of leaves or branches. The increase in the population of arthropods with ground cover by A. mangium saplings age increase indicates the positive impact by this plant on the recovery process of degraded areas.
\end{abstract}

Keywords: arthropods, diversity, Formicidae, pollinating insects, ecological interactions.

\begin{abstract}
Resumo
Acacia mangium é uma espécie pioneira, de rápido crescimento e utilizada na recuperação de áreas degradadas. Os objetivos foram avaliar insetos e aranhas, seus índices ecológicos e interações com plantas de $A$. mangium em área tropical degradada em processo de recuperação. O delineamento experimental foi inteiramente casualizado com 24 repetições, com os tratamentos representados pelos primeiro e segundo anos após a plantio de A. mangium. Os números de folhas/galhos, galhos/plantas e cobertura do solo por plantas de A. mangium, de Hemiptera: Phenacoccus sp. e Pachycoris torridus; Hymenoptera: Tetragonisca angustula e Trigona spinipes, Brachymyrmex sp., Camponotus sp. e Cephalotes sp.; Blattodea: Nasutitermes sp. e Neuroptera: Chrysoperla sp.; a abundância, riqueza de espécies de insetos polinizadores, formigas cuidadoras e a abundância de predadores de Sternorrhyncha foram maiores no segundo ano após o plantio. Os números de Hemiptera: Aethalium reticulatum, Hymenoptera: Camponotus sp., Cephalotes sp., Polybia sp., T. angustula, T. spinipes, formigas cuidadoras, insetos polinizadores, predadores de Sternorrhyncha e a riqueza de espécies de formigas cuidadoras foram maiores em plantas de $A$. mangium com maior altura e número de folhas ou galhos. $O$ aumento populacional de artrópodes e da cobertura do solo com o processo de envelhecimento das plantas de A. mangium indicam impacto positivo dessa planta na recuperação de áreas degradadas.
\end{abstract}

Palavras-chave: artrópodes, diversidade, Formicidae, insetos polinizadores, interações ecológicas.

\section{Introduction}

Human action usually degrades natural ecosystems, especially with agricultural systems management, necessary to maintain population and economic growth

(García-Orth and Martínez-Ramos, 2011). The recovery of these areas is essential but slow (Amaral et al., 2013; Reis et al., 2015). Species of the Fabaceae family (Fabales)

*e-mail: germano.demolin@gmail.com

Received: May 12, 2021 - Accepted: September 3, 2021 
are used to recover degraded areas worldwide, especially with Acacia mangium Willd, due to the fast growth, rusticity, high adaptability to acidic and infertile soils and nitrifying potential (Wang et al., 2013; Caldeira et al., 2018; Silva et al., 2020). The high rates of nitrogen fixation by A. mangium, due to its symbiosis with diazotrophic bacteria, increases the biomass production and nutrient input via litter, favoring plant succession (Paula et al., 2018; Silva et al., 2020). Acacia mangium wood is used to build furniture, cabinets, frames, doors and window components, boxes and crates and to produce coal, coal briquettes and activated carbon (Hegde et al., 2013). Insects such as Aethalion reticulatum (Linnaeus, 1767) (Hemiptera: Aethalionidae), Oncideres mirim (Martins and Galileo, 1996) and Oncideres ocularis (Thomson, 1868) (Coleoptera: Cerambycidae), and Trigona spinipes (Fabricius, 1793) (Hymenoptera: Apidae) can damage A. mangium trees (Lemes et al., 2012, 2013; Silva et al., 2015, 2020).

Arthropod respond to environmental changes and thus used as bioindicators (Prosser et al., 2016; Pereira et al., 2018). The ecological indices (e.g. diversity) of these organisms allow to evaluated modifications on ecological structures, as reduction in the species richness in communities (Pereira et al., 2018). The reproduction, growth, and survival of phytophagous insects and of their natural enemies vary with fertilization, plant age, leaf mass, chemical and nutritional defenses (Bowers and Stamp, 1993; Oliveira et al., 2014) and their abundance and diversity are greater in larger plants as biogeographic islands (BGI) with decreased chances of endangered species extinction (Kitahara and Fujii 1997; Burns, 2016; Leite et al., 2017). Nevertheless, competition between arthropod groups by interference is common (Bhuyain and Lim, 2019, Leite et al., 2021a, b) with death, aggressive behavior, and the production of chemicals (e.g. pheromones) (Boulay et al., 2019). Competition on the exploratory activity includes resource depletion with high density-dependent mortality rates and reproduction failure (Boulay et al., 2019). Tending ants (e.g. Camponotus sp.) protect Hemiptera (e.g. A. reticulatum) against natural enemies in exchange of honeydew, a carbohydrate-rich food that contains glucose, fructose, sucrose, free amino acids, lipids, starch, minerals, and vitamin B (Stadler and Dixon, 2005; Zanuncio et al., 2015; Araujo et al., 2016).

The objectives of this research were to study the abundance, diversity, and species richness of insects and spiders as bioindicators and the possible interactions (competition, predation, and protocooperation) between arthropod groups on young $A$. mangium trees (saplings in the vegetative stage) in a tropical degraded area. Five hypotheses were tested: i) the crown of oldest $A$. mangium saplings is higher (highest $\mathrm{BGI}$ ) with greatest litter production increasing the recovery of the degraded area; ii) abundance, diversity and species richness of herbivorous and pollinating insects and of predators and tending ants are greatest in oldest saplings due to their larger crowns (highest BGI); iii) the abundance of tending ants and predators can be directly proportional to that of Hemiptera phytophagous and prey, respectively; iv) the greatest abundance of ants can reduce that of predators and chewing insects, and v) competition between insects can occur.

\section{Material and Methods}

\subsection{Experimental site}

The study was carried out in a degraded area $(\approx 1$ ha) at the "Instituto de Ciências Agrárias da Universidade Federal de Minas Gerais" (ICA/UFMG), city of Montes Claros, Minas Gerais State, Brazil (latitude 1651'38 S, longitude 445ㅜㅇㅡ" W, altitude $943 \mathrm{~m}$ ) from April 2015 to February 2017 - 24 months. The area is degraded due to soil losses and changes in soil chemistry and hydrology (Milton et al., 1994; Whitford, 2001). This area, according to the Köppen climate classification, is dry tropical; with annual rainfall between 1,000-1,300 mm, dry winter, and average annual temperature $\geq 18^{\circ} \mathrm{C}$ (Alvares et al., 2013). The soil is of the Neosol Litolic type with an Alic horizon (Santana et al., 2016), and its physical-chemical characteristics have been described (Silva et al., 2020).

\subsection{Experimental design}

Acacia mangium seedlings were produced from seeds obtained on trees grown at the ICA/UFMG and planted in plastic bags $(16 \times 24 \mathrm{~cm})$ in a nursery with a substrate with $30 \%$ organic compost, $30 \%$ clay soil, $30 \%$ sand, and 10\% reactive natural phosphate $(160 \mathrm{~g})$ in March 2014. In September of this year, $30 \mathrm{~cm}$ tall saplings were planted in holes $(40 \times 40 \times 40 \mathrm{~cm})$, spaced by two meters between each one, in six parallel lines on flat terrain and $2 \mathrm{~m}$ between lines, with four plants per line, and fertilized in a single dose, with $20 \mathrm{~L}$ of dehydrated sewage sludge/hole (Nogueira et al., 2007). The saplings were irrigated twice a week until the beginning of the rainy season. The design was completely randomized with 24 replications (one sapling each), with treatments in the first and second years after planting the $A$. mangium seedlings.

\subsection{Vegetal mass produced and ground cover}

Numbers of leaves/branch and branches/sapling and the percentage of ground cover by litter, herbaceous and grassy plants were evaluated visually and monthly per plot $\left(1 \mathrm{~m}^{2}\right)$ in the crown projection of each one of the 24 A. mangium saplings.

\subsection{Arthropods and their ecological indices and interactions}

All insects (Eusocial Formicidae) and spiders were counted between 7:00 A.M. and 11:00 A.M., by visual observation, every two weeks on the adaxial and abaxial surfaces of the first 12 leaves expanded per A. mangium sapling. These leaves were assessed, randomly, on branches (one leaf per position) in the basal, middle and apical parts of the canopy- vertical axis - ( 0 to $33 \%, 33$ to $66 \%$ and 66 to $100 \%$ of total sapling height, respectively) and in the north, south, east and west directions - horizontal axis. A total of 12 leaves/sapling/evaluation were observed in each of the $24 \mathrm{~A}$. mangium saplings starting six months after 
transplanting them and lasting 24 months, covering the entire sapling (vertical and horizontal axis), capturing the highest possible number of arthropods (insects and spiders), especially the rarest ones. The evaluator approached, carefully, firstly assessed the adaxial leaf surface and, if it was not possible to visualize the abaxial one, with a delicate and slow movement, lifted the leaf to visualize it. The leaf position of $A$. mangium saplings is generally tilted upwards, facilitating the visual assessment of arthropods. Insects with great mobility (e.g. Orthoptera), that flew, on approach, were counted as long as they were recognized (e.g. Order). The arthropods (insects and spiders) were not removed from the saplings during the evaluation.

A few arthropod specimens (up to three individuals) per species were collected using an aspirator (two hours per week), at the beginning of the study (between transplantation and first evaluation, six months after), stored in flasks with $70 \%$ alcohol, separated into morphospecies, and sent to specialists for identification (see acknowledgments). Any visible arthropod, not yet computed in previous evaluations was collected, coded and sent to a taxonomist of its group. The interactions between ants and Hemiptera due to their behavior of tending (i.e. consuming honeydew and antennating Hemiptera) identified them with protocooperation behavior on $A$. mangium saplings.

\subsection{Statistical analysis}

Each replication is the total number of individuals collected on 12 leaves (three heights and four sides of the sapling). The ecological indices (abundance, diversity, and species richness) were calculated per group (e.g. chewing insects) in the treatments (years 1 and 2) using the BioDiversity Professional, Version 2 software ( 1997 The Natural History Museum) (Krebs, 1989). Abundance and species richness are the total number of individuals and species, respectively, per sampling (Begon et al., 2007). Diversity was calculated using Hill's formula (1st order): $\mathrm{N} 1=\exp \left(\mathrm{H}^{\prime}\right)$, where $\mathrm{H}^{\prime}$ is the Shannon-Weaver diversity indices, that calculates diversity and the current number of species (Hill, 1973).

The data on abundance, diversity, and species richness of phytophagous insects, pollinator insects and natural enemies were submitted to a non-parametric statistical hypothesis, Wilcoxon signed-rank test $(\mathrm{P}<0.05)$ (Wilcoxon, 1945) using the statistical software "Sistema para Análise Estatística e Genética” (SAEG), version 9.1 (SAEG, 2007) (Supplier: "Universidade Federal de Viçosa”). Data were also subjected to second degree or principal component regressions $(P C R)(P<0.05)$, when linear to verify the possible interactions (e.g. protocooperation) between arthropod groups (e.g. tending ants and Hemiptera phytophagous). Simple equations were selected based on the criteria: i) data distribution in the figures (linear or quadratic response), ii) the most significant parameters were used in these regressions ( $p$-value $<0.05$ ), iii) p-value< 0.05 and $F$ of the analysis of variance of these regressions, and iv) the determination coefficient of these equations $\left(\mathrm{R}^{2}\right)$. PCR uses principal component analysis, based on a covariance matrix to perform regression. It reduces the size of regression, excluding the dimensions contributing to collinearity, which are, linear relationships between the independent variables (Bair et al., 2006). The parameters used in these equations were significant $(\mathrm{P}<0.05)$ due to variable selection by the "Stepwise" method with the statistical software. The data presented in the text are the significant ones $(P<0.05)$ and the rest are in the supplementary material I.

\section{Results}

\subsection{Vegetal mass production and ground cover}

Numbers of leaves/branch, branches/sapling, and ground cover (litter, herbaceous, and grassy plants) were higher on A. mangium saplings in the second year of planting (Table 1 ).

\subsection{Arthropods and their ecological indices}

Numbers of Blattodea: Nasutitermes sp. (Termitidae); Hemiptera: Phenacoccus sp. (Pseudococcidae), and Pachycoris torridus (Scopoli, 1772) (Scutelleridae); Hymenoptera: Tetragonisca angustula (Latreille, 1811) and T. spinipes (Apidae), Brachymyrmex sp., Camponotus sp., and Cephalotes sp. (Formicidae); and Neuroptera: Chrysoperla sp. (Chrysopidae) were higher on A. mangium saplings in the second year after planting. Abundance and species richness of pollinating insects, tending ants, and abundance of Sternorrhyncha predators were greater on A. mangium saplings in the second year. Numbers of $A$. reticulatum, Camponotus sp., Cephalotes sp., Polybia sp. (Hymenoptera: Vespidae), T. angustula, and T. spinipes were higher on A. mangium saplings with greatest numbers of leaves or branches. Abundances of tending ants, pollinating insects, Sternorrhyncha predators and species richness of tending ants were greater on A. mangium saplings with

Table 1. Number of branches/sapling and leaves/branch, percentage of ground cover per Acacia mangium (Fabaceae) sapling (mean \pm SE) and planting year.

\begin{tabular}{|c|c|c|c|c|}
\hline \multirow{2}{*}{ Variables } & \multicolumn{2}{|c|}{ Year } & \multicolumn{2}{|c|}{ TW $^{*}$} \\
\hline & First & Second & $V T^{E}$ & $\boldsymbol{P}$ \\
\hline Leaves/branch & $22.90 \pm 0.65$ & $43.92 \pm 2.94$ & 5.42 & 0.00 \\
\hline Branches/sapling & $34.40 \pm 1.64$ & $49.20 \pm 3.32$ & 3.53 & 0.00 \\
\hline Ground cover & $14.66 \pm 1.57$ & $37.00 \pm 2.99$ & 4.62 & 0.00 \\
\hline
\end{tabular}

${ }^{*} \mathrm{TW}=$ Test of Wilcoxon; ${ }^{\mathrm{E} V T}=$ value of test; $\mathrm{n}=24$ per treatment. 
bigger vegetal mass (e.g. A. mangium leaves). However, the numbers of Araneae: Araneidae and Oxyopidae; Coleoptera: Cerotoma sp., Stereoma anchoralis (Lacordaire, 1848) (Chrysomelidae), and total Coleoptera; Hemiptera: Bemisia sp. (Aleyrodidae), Membracidae, and Bladina sp. (Nogodinidae); Hymenoptera: Apis mellifera (Linnaeus, 1758) (Apidae), Ectatoma sp. and Pheidole sp. (Formicidae); and total Orthoptera were higher on saplings in the first year after planting. Abundance, species richness of chewing insects (higher defoliation), and spiders were greater on saplings in the first year. The number of Pheidole sp., and the abundance and species richness of chewing insects were lower on leafiest saplings (Tables 2-4).

\subsection{Possible protocooperation, predation, and competition}

The numbers of T. spinipes and Pheidole sp. correlated, positively, with that of $A$. reticulatum and those of Araneidae with Tropidacris collaris (Stoll, 1813)(Orthoptera: Romaleidae) and Parasyphraea sp. (Coleoptera: Chrysomelidae). Diversity and species richness of Sternorrhyncha predators correlated, positively, with those of Hemiptera phytophagous, and abundance of spiders with that of chewing insects. However, the number of Bemisia sp. correlated, negatively, with that of chewing insects; those of $T$. spinipes and Dolichopodidae (Diptera) with tending ants; and those of $T$. spinipes with total predators (Table 4).

\section{Discussion}

A greater vegetal mass production and ground cover (e.g. litter) of A. mangium saplings (highest BGI) increased abundance of sap-sucking insects and tending ants in the second year after planting. Therefore, numbers of predators, defoliators and, in some situations, reduced, stirring competition between groups of insects (Leite et al., 2012a, b, 2017; Silva et al., 2020).

Larger canopies (e.g. branches/sapling) and ground cover (e.g. litter) of $A$. mangium saplings in the second year after planting confirm the first hypothesis that older sapling helps to recuperate a degraded area, corroborating the greater biomass production (wood, branch, leaf, and

Table 2. Order, family, and species of spiders (Class Arachnidae) and insects (Class Insecta), and percentage of defoliation by insects per Acacia mangium (Fabaceae) sapling (mean $\pm \mathrm{SE}$ ) and planting year.

\begin{tabular}{|c|c|c|c|c|}
\hline \multirow{2}{*}{ Order: family, species } & \multicolumn{2}{|c|}{ Year } & \multicolumn{2}{|c|}{ TW $^{*}$} \\
\hline & First & Second & $V T^{E}$ & $\boldsymbol{P}$ \\
\hline Ara.: Araneidae, none identified & $0.63 \pm 0.17$ & $0.21 \pm 0.10$ & 1.95 & 0.02 \\
\hline Oxyopidae, none identified & $0.58 \pm 0.17$ & $0.17 \pm 0.07$ & 1.98 & 0.02 \\
\hline Blat. $\S$ : Termitidae, Nasutitermes sp. & $6.46 \pm 5.30$ & $29.92 \pm 14.07$ & 2.31 & 0.01 \\
\hline Col.: Chrysomelidae, Cerotoma sp. & $0.21 \pm 0.08$ & $0.00 \pm 0.00$ & 2.34 & 0.01 \\
\hline Stereoma anchoralis Lacordaire & $0.21 \pm 0.13$ & $0.00 \pm 0.00$ & 1.77 & 0.03 \\
\hline Total Coleoptera & $1.58 \pm 0.53$ & $0.42 \pm 0.13$ & 2.22 & 0.01 \\
\hline Hem.: Aleyrodidae, Bemisia sp. & $2.71 \pm 1.09$ & $0.04 \pm 0.04$ & 2.12 & 0.01 \\
\hline Membracidae, none identified & $0.46 \pm 0.17$ & $0.33 \pm 0.33$ & 2.18 & 0.01 \\
\hline Nogodinidae, Bladina sp. & $0.13 \pm 0.06$ & $0.00 \pm 0.00$ & 1.77 & 0.03 \\
\hline Pseudococcidae, Phenacoccus sp. & $0.00 \pm 0.00$ & $2.21 \pm 1.18$ & 2.06 & 0.01 \\
\hline $\begin{array}{l}\text { Scutelleridae, Pachycoris torridus } \\
\text { Scopoli }\end{array}$ & $0.00 \pm 0.00$ & $0.17 \pm 0.09$ & 1.77 & 0.03 \\
\hline Hym.: Apidae, Apis mellifera L. & $0.38 \pm 0.15$ & $0.00 \pm 0.00$ & 2.59 & 0.00 \\
\hline Tetragonisca angustula Latreille & $0.33 \pm 0.13$ & $1.04 \pm 0.22$ & 2.63 & 0.00 \\
\hline Trigona spinipes Fabr. & $0.67 \pm 0.28$ & $4.00 \pm 1.30$ & 2.63 & 0.00 \\
\hline Formicidae, Brachymyrmex sp. & $3.04 \pm 1.02$ & $37.17 \pm 10.56$ & 2.62 & 0.00 \\
\hline Camponotus sp. & $0.63 \pm 0.26$ & $8.58 \pm 2.04$ & 4.94 & 0.00 \\
\hline Cephalotes sp. & $0.17 \pm 0.16$ & $6.88 \pm 3.04$ & 2.82 & 0.00 \\
\hline Ectatoma sp. & $0.92 \pm 0.26$ & $0.17 \pm 0.09$ & 2.59 & 0.00 \\
\hline Pheidole sp. & $4.00 \pm 0.74$ & $1.13 \pm 0.29$ & 3.06 & 0.00 \\
\hline Neu.: Chrysopidae, Chrysoperla sp. & $0.00 \pm 0.00$ & $0.13 \pm 0.06$ & 1.77 & 0.03 \\
\hline Total Orthoptera & $1.42 \pm 0.28$ & $0.75 \pm 0.17$ & 1.71 & 0.04 \\
\hline Defoliation & $6.69 \pm 0.29$ & $5.87 \pm 0.31$ & 2.17 & 0.01 \\
\hline
\end{tabular}

${ }^{*} \mathrm{TW}=$ Test of Wilcoxon; ${ }^{\mathrm{E} V T}=$ value of test; ${ }^{\S}$ observed on trunck; $\mathrm{n}=24$ per treatment. 
Table 3. Abundance, diversity and species richness of phytophagous chewing insects, Hemiptera phytophagous, pollinators, tending ants, Sternorrhyncha predators, and spiders per Acacia mangium sapling (Fabaceae) (mean \pm SE) and planting year.

\begin{tabular}{|c|c|c|c|c|}
\hline \multirow{2}{*}{ Variables } & \multicolumn{2}{|c|}{ Year } & \multicolumn{2}{|c|}{ TW $^{*}$} \\
\hline & First & Second & $V T^{E}$ & $\boldsymbol{P}$ \\
\hline Chewer abundance & $3.08 \pm 0.67$ & $1.29 \pm 0.24$ & 2.32 & 0.01 \\
\hline Chewer diversity & $2.61 \pm 0.53$ & $2.10 \pm 0.48$ & 0.56 & 0.28 \\
\hline Chewer species richness & $1.96 \pm 0.30$ & $1.21 \pm 0.19$ & 1.80 & 0.03 \\
\hline Hemiptera abundance & $8.29 \pm 4.14$ & $6.04 \pm 2.63$ & 0.99 & 0.16 \\
\hline Hemiptera density & $2.10 \pm 0.54$ & $1.48 \pm 0.31$ & 0.32 & 0.37 \\
\hline Hemiptera species richness & $1.67 \pm 0.26$ & $1.13 \pm 0.19$ & 1.44 & 0.07 \\
\hline Pollinator abundance & $1.38 \pm 0.37$ & $5.04 \pm 1.31$ & 2.80 & 0.00 \\
\hline Pollinator diversity & $1.11 \pm 0.28$ & $0.99 \pm 0.23$ & 0.13 & 0.44 \\
\hline Pollinator species richness & $0.79 \pm 0.18$ & $1.25 \pm 0.15$ & 2.05 & 0.02 \\
\hline Ant abundance & $10.63 \pm 1.59$ & $56.88 \pm 11.24$ & 3.54 & 0.00 \\
\hline Ant diversity & $4.71 \pm 0.70$ & $3.55 \pm 0.47$ & 1.15 & 0.12 \\
\hline Ant species richness & $2.63 \pm 0.25$ & $3.21 \pm 0.30$ & 1.68 & 0.04 \\
\hline Predator abundance & $1.13 \pm 0.24$ & $2.38 \pm 0.53$ & 2.06 & 0.01 \\
\hline Predator diversity & $1.23 \pm 0.31$ & $1.50 \pm 0.35$ & 0.49 & 0.30 \\
\hline Predator species richness. & $0.83 \pm 0.15$ & $1.04 \pm 0.16$ & 0.98 & 0.16 \\
\hline Spider abundance & $1.79 \pm 0.30$ & $0.71 \pm 0.16$ & 2.56 & 0.00 \\
\hline Spider diversity & $1.57 \pm 0.58$ & $0.85 \pm 0.27$ & 0.28 & 0.38 \\
\hline Spider richness & $1.33 \pm 0.22$ & $0.67 \pm 0.15$ & 2.21 & 0.01 \\
\hline
\end{tabular}

${ }^{*} \mathrm{TW}=$ Test of Wilcoxon; ${ }^{\mathrm{E} V T}=$ value of test; $\mathrm{n}=24$ per treatment.

bark) with old increase of Acacia mearnsii (De Wild, 1925), Ateleia glazioviana (Baill,1881) and Mimosa scabrella (Benth, 1842) (Fabales: Fabaceae), and Eucalyptus grandis (W. Hill ex Maiden, 1862) (Myrtales: Myrtaceae) (Eloy et al., 2018). The recovery of degraded areas is slow as reported for a deactivated gold mine in Diamantina, Minas Gerais State, Brazil, with 707 and 909 plants with a diameter $\geq 3.0 \mathrm{~cm}$ of 29 and 30 plant families, 57 and 64 plant genus, and 77 and 86 plant species in the first (2008) and second (2010) inventories, respectively (Amaral et al., 2013). The regeneration resilience of the Brazilian savannah (Cerrado)is, usually, high after the first cut, but the succession after almost four decades in Nova Xavantina municipality, Mato Grosso State, Brazil was still in an intermediate stage (Reis et al., 2015). This expresses the recovery potential of $A$. mangium plants with rapid growth, even in degraded soils, due to its efficient nitrogen fixation (Cipriani et al., 2013; Silva et al., 2020) and with flowers attracting pollinating insects (Wang et al., 2013; Caldeira et al., 2018; Silva et al., 2018, 2020).

Greater numbers of sap-sucking insects (e.g. Phenacoccus sp.) and the termite Nasutitermes sp., pollinators (e.g. T. angustula), tending ants (e.g. Brachymyrmex sp.) and Sternorrhyncha predators (e.g. Chrysoperla sp.) on A. mangium saplings, in the second year of planting, are, probably, due to the greater numbers of leaves (e.g. Camponotus sp.) and branches (e.g. A. reticulatum) on these saplings (highest BGI). The abundance and species richness of pollinating insects and tending ants, and abundance of Sternorrhyncha predators were also higher on A. mangium saplings in the second year of planting, probably, due to the higher vegetal mass production. This partially confirms the second hypothesis that with higher BGI allow greater abundance of herbivorous and pollinating insects and, consequently, tending ants and predators (Schmitz, 2008; Leite et al., 2017; Silva et al., 2020). The numbers of pollinating insects (e.g. T. spinipes) and tending ants (e.g. Camponotus sp.) were four to six times higher on $A$. mangium saplings, in the second year after planting due to their larger canopies, and, consequently, with bigger numbers of extrafloral nectaries (leaf base) with greater food supply (Hegde et al., 2013). These results validate those of Brachymyrmex sp., Camponotus sp., and T. spinipes on Leucaena leucocephala (Lam, 1996) (Fabales: Fabaceae) plants (Damascena et al., 2017), and Brachymyrmex obscurior (Forel, 1893) (Hymenoptera: Formicidae) on Acacia pennatula (Schltdl. and Cham. Benth, 1832) (Fabales: Fabaceae) plants (Moya-Raygoza, 2005). Taller A. mangium saplings, in the second year after planting, may have functioned as BGIs with high food supply and shelter for arthropods and reducing the extinction risks of rarer species (Kitahara and Fujii, 1997; Burns, 2016; Leite et al., 2017). Numbers of pollinating insects and Nasutitermes sp. were higher on A. mangium saplings with larger crowns, similar to that reported for galling insects on Caryocar brasiliense (A. St.-Hil., 1828) (Malpighiales: 
Table 4. Relationships between abundance (Abun.) of chewing insects (Chew.), tending ants (Ants), spiders (Spid.), pollinating insects (Pol.), Hemiptera phytophagous (Hem.), Sternorrhyncha predators (Pred.) and total predators (Tot.Pred.), diversity (D.) of Hem. and Pred., species richness (S.R) of Chew., Hem., Ants and Pred., numbers of Aethalium reticulatum (Aret.), Bemisia sp. (Bem.), Araneidae (Aran.), Camponotus sp. (Camp.), Cephalotes sp. (Ceph.), Dolichopodidae (Doli.), Parasyphraea sp. (Para.), Pheidole sp. (Phei.), Polybia sp. (Poly.), Tetragonista angustula (Tangu), Trigona spinipes (Tspi.), Tropidacris collaris (Tcoll.), branches/sapling (Branches) and leaves/ branch (Leaves) per Acacia mangium sapling (Fabaceae).

\begin{tabular}{|c|c|c|c|}
\hline Principal component regressions & $\mathbf{R}^{2}$ & $\boldsymbol{F}$ & $\boldsymbol{P}$ \\
\hline Aret. $=-11.87+1.98 \times$ Pheid. $+1.12 \times$ Tspi. $+0.18 \times$ Branches & 0.26 & 5.24 & 0.00 \\
\hline Aran.$=0.18+0.34 \times$ Para.$+0.24 \times$ Tcoll. & 0.22 & 6.15 & 0.00 \\
\hline Pheid. $=4.76+0.05 \times$ Aret. $-0.07 x$ Leaves & 0.19 & 5.18 & 0.01 \\
\hline Tspi. $=-2.80+0.13 \times B r a n c h e s+0.10 \times$ Aret.-0.13xAbun. Tot.Pred. & 0.25 & 4.76 & 0.01 \\
\hline \multicolumn{4}{|l|}{ Simple regressions } \\
\hline Abun. Chew. $=4.42-0.07 \times$ Leaves & 0.14 & 7.58 & 0.01 \\
\hline Abun. Ants $=-22.00+1.67 \times$ Leaves & 0.30 & 19.38 & 0.00 \\
\hline Abun. Spid. $=0.85+0.18 \times$ Abun. Chew. & 0.14 & 7.21 & 0.01 \\
\hline Abun. Pol. $=-1.40+0.11 \times$ Branches & 0.10 & 5.36 & 0.03 \\
\hline Abun. Pred. $=0.24+0.05 x$ Leaves & 0.10 & 5.25 & 0.03 \\
\hline D. Pred. $=0.91+0.26 x D$. Hem. & 0.12 & 5.96 & 0.02 \\
\hline S.R. Chew. $=2.66-0.03 \times$ Leaves & 0.14 & 7.20 & 0.01 \\
\hline S.R. Ants $=1.67+0.04 \times$ Leaves & 0.16 & 8.76 & 0.00 \\
\hline S.R. Pred. $=0.65+0.21 \times S . R$. Hem. & 0.10 & 4.83 & 0.03 \\
\hline Camp. $=-3.60+0.25 x$ Leaves & 0.20 & 11.52 & 0.00 \\
\hline Ceph. $=-13.10+0.50 \times$ Leaves & 0.45 & 37.67 & 0.00 \\
\hline Tangu. $=-0.20+0.03 \times$ Leaves & 0.16 & 8.96 & 0.00 \\
\hline Bem. $=-0.65+1.43 x$ Abun. Chew. $-0.10 x$ Abun. Chew. ${ }^{2}$ & 0.16 & 4.22 & 0.02 \\
\hline Tspi. $=-0.17+0.15 \times$ Abun. Ants- $0.001 \times A b u n$. Ants $^{2}$ & 0.19 & 5.13 & 0.01 \\
\hline Doli. $=0.64+0.03 \times$ Abun. Ants $-0.0002 \times A b u n$. Ants ${ }^{2}$ & 0.14 & 3.77 & 0.03 \\
\hline
\end{tabular}
$\mathrm{n}=48$.

Caryocaraceae) and Macairea radula (Bonpl. DC, 1828) (Myrtales: Melastomataceae), and Carpatolechia proximella (Hübner, 1796) (Lepidoptera: Gelechiidae) on Picea abies (L. Karst., 1753) (Pinales: Pinaceae) plants with larger crowns (Lara et al., 2008; Zvereva et al., 2014; Leite et al., 2017). On the other hand, the greater abundance, species richness, and defoliation on A. mangium saplings by chewing insects (e.g. S. anchoralis and T. collaris) and, consequently, predatory spiders (e.g. Araneidae), sap-sucking insects (e.g. Bemisia sp.), and tending ants (e.g. Pheidole sp.), in the first year after planting, are, probably, due to the rapid growth, softest leaves, higher nitrogen content (e.g. leaf protein and free amino acids in the sap) via fertilization of dehydrated sewage sludge (e.g. rich in nitrogen and other minerals) (Taiz et al., 2017; Silva et al., 2020). Bemisia sp. is an initial pest of annual crops and preferring new leaves of younger Glycine max (L., 1737) (Fabales: Fabaceae) plants with higher free amino acid concentration in the sap (most nutritious food) (Cruz et al., 2016).

The increase in the numbers of predators (e.g. spiders) with that of phytophagous insects (e.g. defoliating), that of Araneidae with T. collaris and Parasyphraea sp., that of tending ants Pheidole sp. with A. reticulatum, and diversity and species richness of Sternorrhyncha predators with those of Hemiptera phytophagous on A. mangium saplings confirm the third hypothesis. The higher numbers of Hemiptera phytophagous and prey can result in greater numbers of tending ants and predators, respectively (Schmitz, 2008; Leite et al., 2012a). The direct correlation between sapsucking insects and ants of the genera Camponotus and Brachymyrmex is due to the associations between these insect groups with mutual benefits (Novgorodova, 2015; Sanchez et al., 2020). This is similar to that reported for the greater numbers of Dikrella caryocar (Coelho, Leite and Da-Silva, 2014)(Hemiptera: Cicadellidae) and Pseudoccocus sp. (Hemiptera: Pseudococcidae) with Crematogaster sp. (Hymenoptera: Formicidae) on C. brasiliense trees (Leite et al., 2012a, 2015). Spiders reduced insect damage, especially by defoliators, in agroecosystems in the USA and Italy (Landis et al., 2000; Venturino et al., 2008), in 12 landscapes in the low mountain ranges of Central Hesse (Germany) (Öberg et al., 2008), and on C. brasiliense (Leite et al., 2012b) and A. mangium (Silva et al., 2020) trees in the cerrado and pastures in Brazil. The larger numbers of tending ants (e.g. Pheidole sp. with A. reticulatum), associated with sap-sucking insects may also have contributed to the greater abundance of chewing insects (e.g. Cerotoma sp.) and spiders (e.g. Oxyopidae), in the first 
year after planting $A$. mangium saplings. These facts confirm the fourth hypothesis that higher numbers of tending ants can decrease those of chewing insects and predators (Leite et al., 2012b; Wäckers et al., 2017). Trophobiotic interactions between ants (protection against natural enemies) and Sternorryncha (Hemiptera) (supplier of sugary substance - food) are one of the main mechanisms explaining the maintenance and superabundance of ants in ecosystems (Klimes et al., 2018) decreasing that of natural enemies, including Sternorrhyncha predators, with a negative impact on the biological control of sap-sucking insects (Wäckers et al., 2017; Kaneko, 2018; Tong et al., 2019). On the other hand, ants can reduce defoliation and fruit-boring insect populations (e.g. Coleoptera and Lepidoptera) on C. brasiliense trees (Leite et al., 2012b; Gonthier et al., 2013; Fagundes et al., 2017; Dassou et al., 2019) besides, being bioindicators of the recovery of degraded areas (Sanchez, 2015).

The greater abundance of chewing insects and Bemisia sp., in the first, and tending ants and T. spinipes, in the second year, after planting the $A$. mangium saplings and the reduction in the number of these sap-sucking and pollinating insects by the larger numbers of chewing insects and ants, confirm the fifth hypothesis that competition between insects can occur in those environments (Leite et al., 2017). The direct correlation between T. spinipes and A. reticulatum is similar to that of Trigona hyalinata (Lepeletier, 1836) (Santos et al., 2019) on Clitoria fairchildiana (Howard, 1967) (Fabales: Fabaceae) branches (Oda et al., 2009). The possible competition for honeydew produced by this sap-sucking insect between $T$. spinipes and tending ants (e.g. Pheidole sp.) on A. mangium saplings favor this bee with strong jaws, aggressivity and attacking and releasing repellent substances on potential predators or competitors (e.g. ants) for the honeydew insects that suck sap and live in colonies (Schorkopf et al., 2009). The competition, for food and space, between $T$. spinipes $\times$ A. mellifera and $T$. angustula on cucurbits and $A$. mangium trees (Serra and Campos, 2010; Silva et al., 2020), and between four-leaf galling insects (Hymenoptera), aphids and beetles on $C$. brasiliense trees (Leite et al., 2012b, 2017) was also reported. Phylogenetic proximity favors the formation and maintenance of mixed species groups (eussocial or gregarious), probably, due to easier communication between members of similar size, lifespan, and displacement (Boulay et al., 2019). On the other hand, sharing similar ecological niches reduces the availability of food or reproductive partners through competition between species. The balance between the sharing of these resources and competition is crucial to understanding these species clusters and the disproportionate benefits for one species at the expense of anothers (Boulay et al., 2019).

\section{Conclusions}

The numbers of T. collaris ( $\approx 1 /$ sapling) and Bemisia sp. $(\approx 3 /$ sapling $)$ in the first year after planting, A. reticulatum ( $\approx 3 /$ sapling) in the second year, and Nasutitermes sp. $(\approx 30 /$ sapling) and $T$. spinipes ( $\approx 4 /$ sapling) in second year after planting on $A$. mangium saplings deserve attention since they are pests and harmful for this and many other plants. Both the vegetal mass production (e.g. branches) and ground cover (e.g. leaf litter) and the number of arthropods (e.g. tending ants) increased with the $A$. mangium saplings age. This correspondence indicates that the plant is a valuable alternative to recover degraded areas. Also, the increasing numbers of sap-sucking insects impact positively the numbers of tending ants and reduced those of predators, chewing insects, and $T$. spinipes, as the latter competes, with tending ants for food resources (honeydew) from A. reticulatum.

\section{Acknowledgements}

To the Dr. Antônio Domingos Brescovit (Instituto Butantan, São Paulo, Brasil) (Arachnida), Dr Ayr de Moura Bello (Fundação Oswaldo Cruz, Rio de Janeiro, Brasil) (Coleoptera), Dr. Carlos Matrangolo (UNIMONTES, Minas Gerais, Brasil) (Formicidae), Dr. Ivan Cardoso Nascimento (EMBRAPA-ILHÉUS, Bahia, Brasil) (Formicidae), Dr. Luci Boa Nova Coelho (Universidade Federal do Rio de Janeiro, Rio de Janeiro, Brasil) (Cicadellidae), and Dr. Paulo Sérgio Fiuza Ferreira (Hemiptera) (Universidade Federal de Viçosa, Minas Gerais, Brasil) by species identifications. The vouchers are IBSP 36921-36924 (Instituto Butantan, São Paulo, Brasil) for spiders, and 1595/02 and 1597/02 (CDZOO, Universidade Federal do Paraná, Paraná, Brasil) for insects. To the "Conselho Nacional de Desenvolvimento Científico e Tecnológico" (CNPq), "Fundação de Amparo à Pesquisa do Estado de Minas Gerais" (FAPEMIG), and "Programa Cooperativo sobre Proteção Florestal" (PROTEF) do Instituto de Pesquisas Florestais (IPEF)" for financial support.

\section{References}

ALVARES, C.A., STAPE, J.L., SENTELHAS, P.C., GONÇALVES, J.L.M. and SPAROVEK, G., 2013. Köppen's climate classification map for Brazil. Meteorologische Zeitschrift, vol. 22, no. 6, pp. 711-728. http://dx.doi.org/10.1127/0941-2948/2013/0507.

AMARAL, W.G., PEREIRA, I.M., AMARAL, C.S., MACHADO, E.L.M. and RABELO, L.D.O., 2013. Dynamics of the shrub and tree vegetation colonizing an area degraded by gold mined in Diamantina, Minas Gerais State. Ciência Florestal, vol. 23, no. 4, pp. 713-725. http://dx.doi.org/10.5902/1980509812355.

ARAÚJO, E.S., BENATTO, A., MÓGOR, Á.F., PENTEADO, S.C. and ZAWADNEAK, M.A.C., 2016. Biological parameters and fertility life table of Aphis forbesi Weed, 1889 (Hemiptera: Aphididae) on strawberry. Brazilian Journal of Biology = Revista Brasileira de Biologia, vol. 76, no. 4, pp. 937-941. http://dx.doi. org/10.1590/1519-6984.04715. PMid:27143052.

BAIR, E., HASTIE, T., PAUL, D. and TIBSHIRANI, R., 2006. Prediction by supervised principal components. Journal of the American Statistical Association, vol. 101, no. 473, pp. 119-137. http:// dx.doi.org/10.1198/016214505000000628.

BEGON, M., TOWNSEND, C.R. and HARPER, J.L. 2007 [viewed 30 June 2020]. Ecologia: de indivíduos a ecossistemas [online]. 4. ed. Porto Alegre: Artmed, 752 p. Available from: http:/www. esalq. usp.br/lepse/imgs/conteudo_thumb/Ecology-FromIndividualsto-ecosystems-by-Michael-Begon-2007-.pdf 
BHUYAIN, M.M.H. and LIM, U.T., 2019. Interference and exploitation competition between Frankliniella occidentalis and F. intonsa (Thysanoptera: Thripidae) in laboratory assays. The Florida Entomologist, vol. 102, no. 2, pp. 322-328. http://dx.doi. org/10.1653/024.102.0206.

BOUlay, J., AUBERNON, C., RUXTON, G.D., HÉDOUIN, V., DENEUBOURG, J.-L. and CHARABIDZÉ, D., 2019. Mixed-species aggregations in arthropods. Insect Science, vol. 26, no. 1, pp. 2-19. http://dx.doi.org/10.1111/1744-7917.12502. PMid:28657138.

BOWERS, M.D. and STAMP, N.E., 1993. Effects of plant age, genotype and herbivory on Plantago performance and chemistry. Ecology, vol. 74, no. 6, pp. 1778-1791. http://dx.doi.org/10.2307/1939936.

BURNS, K.C., 2016. Native-exotic richness relationships: a biogeographic approach using turnover in island plant populations. Ecology, vol. 97, no. 11, pp. 2932-2938. http:// dx.doi.org/10.1002/ecy.1579. PMid:27870029.

CALDEIRA, M.V.W., FAVALESSA, M., DELARMELINA, W.M., GONÇALVES, E.O. and SANTOS MOURA, R.R., 2018. Sewage sludge assessment on growth of Acacia mangium seedlings by principal components analysis and orthogonal contrasts. Journal of Plant Nutrition, vol. 41, no. 10, pp. 1303-1311. http:// dx.doi.org/10.1080/01904167.2018.1450421.

CIPRIANI, H.N., DIAS, L.E., COSTA, M.D., CAMPOS, N.V., AZEVEDO, A.A., GOMES, R.J., FIALHO, I.F. and AMEZQUITA, S.P.M., 2013. Arsenic toxicity in Acacia mangium willd. and Mimosa caesalpiniaefolia Benth. seedlings. Revista Brasileira de Ciência do Solo, vol. 37, no. 5, pp. 1423-1430. http://dx.doi.org/10.1590/ S0100-06832013000500031.

CRUZ, P.L., BALDIN, E.L., GUIMARÃES, L.R., PANNUTI, L.E., LIMA, G.P., HENG-MOSS, T.M. and HUNT, T.E., 2016. Tolerance of KS-4202 soybean to the attack of Bemisia tabaci biotype B (Hemiptera: aleyrodidae). The Florida Entomologist, vol. 99, no. 4, pp. 600607. http://dx.doi.org/10.1653/024.099.0403.

DAMASCENA, J.G., LEITE, G.L.D., SILVA, F.W.S., SOARES, M.A., GUAÑABENS, R.E.M., SAMPAIO, R.A. and ZANUNCIO, J.C., 2017. Spatial distribution of phytophagous insects, natural enemies, and pollinators on Leucaena leucocephala (Fabaceae) trees in the Cerrado. The Florida Entomologist, vol. 100, no. 3, pp. 558565. http://dx.doi.org/10.1653/024.100.0311.

DASSOU, A.G., VODOUHÉ, S.D., BOKONON-GANTA, A., GOERGEN, G., CHAILlEUX, A., DANSI, A., CARVAL, D. and TIXIER, P., 2019. Associated cultivated plants in tomato cropping systems structure arthropod communities and increase the Helicoverpa armigera regulation. Bulletin of Entomological Research, vol. 109, no. 6, pp. 733-740. http://dx.doi.org/10.1017/ S0007485319000117. PMid:30968787.

ELOY, E., SILVA, D.A.D., CARON, B.O., ELLI, E.F. and SCHWERZ, F., 2018. Effect of age and spacing on biomass production in forest plantations. Revista Árvore, vol. 42, no. 2, pp. 1-11. http://dx.doi. org/10.1590/1806-90882018000200014.

FAGUNDES, R., DÁTTILO, W., RIBEIRO, S.P., RICO-GRAY, V., JORDANO, P. and DEL-CLARO, K., 2017. Differences among ant species in plant protection are related to production of extrafloral nectar and degree of leaf herbivory. Biological Journal of the Linnean Society. Linnean Society of London, vol. 122, no. 1, pp. 71-83. http://dx.doi.org/10.1093/biolinnean/blx059.

GARCÍA-ORTH, X. and MARTÍNEZ-RAMOS, M., 2011. Isolated trees and grass removal improve performance of transplanted Trema micrantha (L.) Blume (Ulmaceae) saplings in tropical pastures. Restoration Ecology, vol. 19, no. 1, pp. 24-34. http://dx.doi. org/10.1111/j.1526-100X.2009.00536.X.

GONTHIER, D.J., ENNIS, K.K., PHILPOTT, S.M., VANDERMEER, J. and PERFECTO, I., 2013. Perfecto, I. Ants defend coffee from berry borer colonization. BioControl, vol. 58, no. 6, pp. 815-820. http:// dx.doi.org/10.1007/s10526-013-9541-z.

HEGDE, M., PALANISAMY, K. and YI, J.S., 2013. Acacia mangium Willd.: a fast growing tree for tropical plantation. Journal of Forest and Environmental Science, vol. 29, no. 1, pp. 1-14. http:// dx.doi.org/10.7747/JFS.2013.29.1.1.

HILL, M.O., 1973. Diversity and evenness: a unifying notation and its consequences. Ecology, vol. 54, no. 2, pp. 427-432. http:// dx.doi.org/10.2307/1934352.

KANEKO, S., 2018. Larvae of the exotic predatory ladybird Platynaspidius maculosus (Coleoptera: Coccinellidae) on citrus tree: prey aphid species and behavioral interactions with aphidattending ants in Japan. Applied Entomology and Zoology, vol. 53, no. 1, pp. 85-91. http://dx.doi.org/10.1007/s13355-017-0531-y.

KITAHARA, M. and FUJII, K., 1997. An island biogeographical approach to the analysis of butterfly community patterns in newly designed parks. Population Ecology, vol. 39, no. 1, pp. 23-35. http://dx.doi.org/10.1007/BF02765247.

KLIMES, P., BOROVANSKA, M., PLOWMAN, N. and LEPONCE, M., 2018. How common is trophobiosis with hoppers (Hemiptera: Auchenorrhyncha) inside ant nests (Hymenoptera: Formicidae)? Novel interactions from New Guinea and a worldwide overview. Myrmecological News, vol. 26, no. 1, pp. 31-45.

KREBS, C.J., 1989 [viewed 2 May 2020]. BioDiversity Pro Versão 2 [software]. Available from: http://biodiversity-pro.software. informer.com/

LANDIS, D.A., WRATTEN, S.D. and GURR, G.M., 2000. Habitat management to conserve natural enemies of arthropod pests in agriculture. Annual Review of Entomology, vol. 45, no. 1, pp. 175-201. http://dx.doi.org/10.1146/annurev.ento.45.1.175. PMid:10761575.

LARA, D.P., OLIVEIRA, L.A., AZEVEDO, I.F.P., XAVIER, M.F., SILVEIRA, F.A.O., CARNEIRO, M.A.A. and FERNANDES, G.W., 2008. Relationships between host plant architecture and gall abundance and survival. Revista Brasileira de Entomologia, vol. 52, no. 1, pp. 78-81. http://dx.doi.org/10.1590/S008556262008000100014.

LEITE, G.L.D., VELOSO, R.V.D.S., ZANUNCIO, J.C., ALMEIDA, C.I.M.E., FERREIRA, P.S.F., FERNANDES, G.W. and SOARES, M.A., 2012b. Habitat complexity and Caryocar brasiliense herbivores (Insecta: Arachnida: Araneae). The Florida Entomologist, vol. 95, no. 4, pp. 819-830. http://dx.doi.org/10.1653/024.095.0402.

LEITE, G.L.D., VELOSO, R.V.D.S., ZANUNCIO, J.C., AZEVEDO, A.M., SILVA, J.L., WILCKEN, C.F. and SOARES, M.A., 2017. Architectural diversity and galling insects on Caryocar brasiliense trees. Scientific Reports, vol. 7, no. 1, 16677. http://dx.doi.org/10.1038/ s41598-017-16954-6. PMid:29192234.

LEITE, G.L.D., VELOSO, R.V.S., AZEVEDO, A.M., ALMEIDA, C.I.M.E., SOARES, M.A., PEREIRA, A.I.A., LEMES, P.G. and ZANUNCIO, J.C., 2021b. Distribution of galling insects and their parasitoids on Caryocar brasiliense tree crowns. Brazilian Journal of Biology = Revista Brasileira de Biologia, vol. 82, pp. e235017. http://dx.doi. org/10.1590/1519-6984.235017. PMid:34076163.

LEITE, G.L.D., VELOSO, R.V.S., MATIOLI, A.L., SOARES, M.A. and LEMES, P.G., 2021a. Seasonal mite population distribution on Caryocar brasiliense trees in the Cerrado domain. Brazilian Journal of Biology = Revista Brasileira de Biologia, vol. 82, pp. e236355. http://dx.doi.org/10.1590/1519-6984.236355. PMid:33729382.

LEITE, G.L.D., VELOSO, R.V.S., ZANUNCIO, J.C., FERNANDES, G.W., ALMEIDA, C.I.M., FERREIRA, P.S.F., ALONSO, J. and SERRÃO, J.E., 2012a. Seasonal abundance of hemipterans on Caryocar brasiliense (Malpighiales: Caryocaraceae) trees in the Cerrado. 
The Florida Entomologist, vol. 95, no. 4, pp. 862-872. http:// dx.doi.org/10.1653/024.095.0407.

LEITE, G.L.D., VELOSO, R.V.S., ZANUNCIO, J.C., FERNANDES, G.W., ALMEIDA, C.I.M., FERREIRA, P.S.F., ALONSO, J. and SERRÃO, J.E., 2015. Cardinal distribution of sucking insects in Caryocar brasiliense (Caryocaraceae) in Cerrado (Brazil). Revista Colombiana de Entomologia, vol. 41, no. 1, pp. 105-111. http:// dx.doi.org/10.1038/s41598-017-16954-6. PMid:29192234.

LEMES, P.G., AFONSO, R., ANJOS, N.D., SARMENTO, R.A., LEITE, P.J.B. and CORONETTI, J.A., 2012. First host record of Oncideres mirim Martins and Galileo, 1996 (Coleoptera: Cerambycidae) on Acacia mangium Willd. (Fabaceae). Coleopterists Bulletin, vol. 66, no. 2, pp. 173-176. http://dx.doi.org/10.1649/072.066.0218.

LEMES, P.G., ANJOS, N. and JORGE, R.I., 2013. Bioecology of Oncideres ocularis Thomson (Coleoptera: Cerambycidae) on Acacia mangium Willd. (Fabaceae).Journal of the Kansas Entomological Society, vol. 86, no. 4, pp. 307-317. http://dx.doi.org/10.2317/ JKES121121.1

MILTON,S.J.,DEAN, W.R.J., DU PLESSIS, M.A. and SIEGFRIED, W.R., 1994. A conceptual model of arid rangeland degradation. Bioscience, vol. 44, no. 2, pp. 70-76. http://dx.doi.org/10.2307/1312204.

MOYA-RAYGOZA, G., 2005. Relationships between the ant Brachymyrmex obscurior (Hymenoptera, Formicidae) and Acacia pennatula (Fabaceae). Insectes Sociaux, vol. 52, no. 2, pp. 105-107. http://dx.doi.org/10.1007/s00040-004-0777-6.

NOGUEIRA, T.A.R., SAMPAIO, R.A., FONSECA, I.M., FERREIRA, C.S., SANTOS, S.E., FERREIRA, L.C., GOMES, E. and FERNANDES, L.A., 2007. Heavy metals and pathogens in maize - cowpea intercropping system fertilized with sewage sludge. Revista Brasileira de Engenharia Agrícola e Ambiental, vol. 11, no. 3, pp. 331-338. http://dx.doi.org/10.1590/S1415-43662007000300014.

NOVGORODOVA, T.A., 2015. Organization of honeydew collection by foragers of different species of ants (Hymenoptera: formicidae). European Journal of Entomology, vol. 112, no. 4, pp. 688-697. http://dx.doi.org/10.14411/eje.2015.077.

ÖBERG, S., MAYR, S. and DAUBER, J., 2008. Landscape effects on recolonisation patterns of spiders in arable fields. Agriculture, Ecosystems E Environment, vol. 123, no. 1-3, pp. 211-218. http:// dx.doi.org/10.1016/j.agee.2007.06.005.

ODA, F.H., AOKI, C., ODA, T.M., DA SILVA, R.A. and FELISMINO, M.F., 2009. Interação entre abelha Trigona hyalinata (Lepeletier, 1836) (Hymenoptera: Apidae) e Aethalion reticulatum Linnaeus, 1767 (Hemiptera: Aethalionidae) em Clitoria fairchildiana Howard (Papilionoideae).EntomoBrasilis, vol. 2, no. 2, pp. 58-60. http:// dx.doi.org/10.12741/ebrasilis.v2i2.41.

OLIVEIRA, M.A., GOMES, C.F.F., PIRES, E.M., MARINHO, C.G.S. and DELLA LUCIA, T.M.C., 2014. Bioindicadores ambientais: insetos como um instrumento desta avaliação. Revista Ceres, vol. 61, suppl., pp. 800-807. http://dx.doi.org/10.1590/0034737x201461000005.

PAULA, R.R., BOUILLET, J.P., GONÇALVES, J.L.M., TRIVELIN, P.C.O., BALIEIRO, F.C., NOUVELLON, Y., OLIVEIRA, J.C.O., DEUS-JUNIOR, J.C., BORDRON, B. and LACLAU, J.P., 2018. Nitrogen fixation rate of Acacia mangium Wild at mid rotation in Brazil is higher in mixed plantations with Eucalyptus grandis Hill ex Maiden than in monocultures. Annals of Forest Science, vol. 75, no. 1, pp. 1-14. http://dx.doi.org/10.1007/s13595-018-0695-9.

PEREIRA, A.P.A., ZAGATTO, M.R.G., BRANDANI, C.B., MESCOLOTTI, D.L., COTTA, S.R., GONÇALVES, J.L.M. and CARDOSO, E.J.N., 2018. Acacia changes microbial indicators and increases $C$ and $\mathrm{N}$ in soil organic fractions in intercropped Eucalyptus plantations. Frontiers in Microbiology, vol. 9, pp. 655. http:// dx.doi.org/10.3389/fmicb.2018.00655. PMid:29670606.
PROSSER, R.S., ANDERSON, J.C., HANSON, M.L., SOLOMON, K.R. and SIBLEY, P.K., 2016. Indirect effects of herbicides on biota in terrestrial edge-of-field habitats: A critical review of the literature. Agriculture, Ecosystems \& Environment, vol. 232, pp. 59-72. http://dx.doi.org/10.1016/j.agee.2016.07.009.

REIS, S.M., MARIMON, B.S., MARIMON-JUNIOR, B.H., GOMES, L., MORANDI, P.S., FREIRE, E.G. and LENZA, E., 2015. Resilience of savanna forest after clear-cutting in the cerrado-amazon transition zone. Bioscience Journal, vol. 31, no. 5, pp. 1519-1529. http://dx.doi.org/10.14393/BJ-v31n5a2015-26368.

SANCHEZ, A., 2015. Fidelity and promiscuity in an ant-plant mutualism: A case study of Triplaris and Pseudomyrmex. PLoS One, vol. 10, no. 12, pp. e0143535. http://dx.doi.org/10.1371/ journal.pone.0143535. PMid:26630384.

SANCHEZ, J.A., LÓPEZ-GALLEGO, E. and LA-SPINA, M., 2020. The impact of ant mutualistic and antagonistic interactions on the population dynamics of sap-sucking hemipterans in pear orchards. Pest Management Science, vol. 76, no. 4, pp. 1422-1434. http://dx.doi.org/10.1002/ps.5655. PMid:31628776.

SANTANA, P.H.L., FRAZÃO, L.A., SANTOS, L.D.F., FERNANDES, L.A. and SAMPAIO, R.A., 2016. Soil attributes and production of Eucalyptus in monoculture and silvopastoral systems in the north of Minas Gerais, Brazil. Journal of Agricultural Science and Technology B, vol. 6, no. 6, pp. 361-370. http://dx.doi. org/10.17265/2161-6264/2016.06.001.

SANTOS, C.F., HALINSKI, R., DOS SANTOS, P.D.S., ALMEIDA, E.A.B. and BLOCHTEIN, B., 2019. Looking beyond the flowers: associations of stingless bees with sap-sucking insects. Naturwissenschaften, vol. 106, no. 3-4, pp. 12. http://dx.doi.org/10.1007/s00114-0191608-y. PMid:30927121.

SCHMITZ, O.J., 2008. Herbivory from individuals to ecosystems. Annual Review of Ecology Evolution and Systematics, vol. 39, no. 1, pp. 133-152. http://dx.doi.org/10.1146/annurev. ecolsys.39.110707.173418.

SCHORKOPF, D.L.P., HRNCIR, M., MATEUS, S., ZUCCHI, R., SCHMIDT, V.M. and BARTH, F.G., 2009. Mandibular gland secretions of meliponine worker bees: further evidence for their role in interspecific and intraspecific defence and aggression and against their role in food source signaling. The Journal of Experimental Biology, vol. 212, no. 8, pp. 1153-1162. http:// dx.doi.org/10.1242/jeb.021113. PMid:19329748.

SERRA, B.D.V. and CAMPOS, L.A.O., 2010. Entomophilic pollination of squash, Cucurbita moschata (Cucurbitaceae). Neotropical Entomology, vol. 39, no.2, pp. 153-159. http://dx.doi.org/10.1590/ S1519-566X2010000200002. PMid:20498949.

SILVA, C.L., DE ROLDÃO, B.C., SANTOS, L.D.T. and HEIN, P.R.G., 2018. Wood and bark of Eucalyptus and Acacia in pure and mixed stands. Floresta e Ambiente, vol. 25, no. 1, pp. 1-8. http://dx.doi. org/10.1590/2179-8087.081914.

SILVA, F.W.S., LEITE, G.L.D., GUAÑABENS, R.E.M., SAMPAIO, R.A., GUSMÃO, C.A.G., SERRÃO, J.E. and ZANUNCIO, J.C., 2015. Seasonal abundance and diversity of arthropods on Acacia mangium (Fabales: Fabaceae) trees as windbreaks in the Cerrado. The Florida Entomologist, vol. 98, no. 1, pp. 170-174. http://dx.doi. org/10.1653/024.098.0129.

SILVA, J.L., LEITE, G.L.D., SOUZA, T.W., SOUZA, S.F.W., SAMPAIO, R.A., AZEVEDO, A.M., SERRÃO, J.E. and ZANUNCIO, J.C., 2020. Diversity of arthropods on Acacia mangium (Fabaceae) and production of this plant with dehydrated sewage sludge in degraded area. Royal Society Open Science, vol. 7, no. 2, pp. 191196. http://dx.doi.org/10.1098/rsos.191196. PMid:32257306. 
SISTEMA PARA ANÁLISES ESTATÍSTICAS - SAEG, 2007 [viewed 30 June 2020]. Sistema para Análises Estatísticas - SAEG versão 9.1 [online]. Available from: http://arquivo.ufv.br/saeg/

STADLER, B. and DIXON, A.F.G., 2005. Ecology and evolution of aphid-ant interactions. Annual Review of Ecology Evolution and Systematics, vol. 36, no. 1, pp. 345-372. http://dx.doi.org/10.1146/ annurev.ecolsys.36.091704.175531.

TAIZ, L., ZEIGER, E., MOLLER, I.M. and MURPHY, A., 2017 [viewed 30 June 2020]. Fisiologia e desenvolvimento vegetal [online]. 6. ed. Porto Alegre: The Art of Medication, 858 p. Available from: https://grupos.moodle.ufsc.br/pluginfile.php/474835/mod resource/ content/0/Fisiologia\%20e\%20desenvolvimento\%20 vegetal\%20-\%20Zair\%206\%C2

TONG, H., AO, Y., LI, Z., WANG, Y. and JIANG, M., 2019. Invasion biology of the cotton mealybug, Phenacoccus solenopsis Tinsley: current knowledge and future directions. Journal of Integrative Agriculture, vol. 18, no. 4, pp. 758-770. http://dx.doi.org/10.1016/ S2095-3119(18)61972-0.

VENTURINO, E., ISAIA, M., BONA, F., CHATTERJEE, S. and BADINO, G., 2008. Biological controls of intensive agroecosystems: wanderer spiders in the Langa astigiana. Ecological Complexity, vol. 5, no. 2, pp. 157-164. http://dx.doi.org/10.1016/j.ecocom.2007.10.003.

WÄCKERS, F.L., ALBEROLA, J.S., GARCIA-MARÍ, F. and PEKAS, A., 2017. Attract and distract: manipulation of a food-mediated protective mutualism enhances natural pest control. Agriculture,
Ecosystems E' Environment, vol. 246, no. 1, pp. 168-174. http:// dx.doi.org/10.1016/j.agee.2017.05.037.

WANG, F., ZHU, W., ZOU, B., NEHER, D.A., FU, S., XIA, H. and LI, Z., 2013. Seedling growth and soil nutrient availability in exotic and native tree species: implications for afforestation in southern China. Plant and Soil, vol. 364, no. 1, pp. 207-218. http://dx.doi. org/10.1007/s11104-012-1353-x.

WHITFORD, W.G., 2001. Repairing damaged wildlands: a process-oriented, landscape-scale approach. Restoration Ecology, vol. 9, no. 2, pp. 249. http://dx.doi.org/10.1046/j.1526100x.2001.009002249.x.

WILCOXON, F., 1945. Individual comparisons by ranking methods. Biometrics Bulletin, vol. 1, no. 6, pp. 80-83. http://dx.doi. org/10.2307/3001968.

ZANUNCIO, A.J.V., SERRÃO, J.E., PEREIRA, A.I.A., SOARES, M.A., WILCKEN, C.F., LEITE, G.L.D. and ZANUNCIO, J.C., 2015. Aethalion reticulatum (Hemiptera: Aethalionidae) feeding on Erythrina speciosa (Fabales: Fabaceae): first record of its host plant and damage characteristics. The Florida Entomologist, vol. 98, no. 1, pp. 175-177. http://dx.doi.org/10.1653/024.098.0130.

ZVEREVA, E., ZVEREV, V. and KOZLOV, M., 2014. High densities of leaf-tiers in open habitats are explained by host plant architecture. Ecological Entomology, vol. 39, no. 4, pp. 470-479. http://dx.doi.org/10.1111/een.12123. 


\section{Supplementary Material}

Supplementary material accompanies this paper.

Supplementary material I. Order, family, and spider (Class Arachnidae) and insect (Class Insecta) species per Acacia mangium (Fabales: Fabaceae) sapling (mean $\pm \mathrm{SE}$ ) and planting year

This material is available as part of the online article from https://www.scielo.br/j/bjb 